GORDANA TOPLIČIĆ-ĆURČIĆ, DUŠAN GRDIĆ, NENAD RISTIĆ, ZORAN GRDIĆ

University of Nis, Faculty of Civil Engineering and Architecture, Nis, Serbia
Scientific paper

UDC:666.94.4:693.75

doi:10.5937/ZasMat1503345T

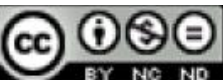

Zastita Materijala 56 (3)

$345-353(2015)$

\title{
Properties, materials and durability of rolled compacted concrete for pavements
}

\begin{abstract}
Roller-Compacted Concrete (RCC) consists of an engineered mixture of dense-graded aggregates, cement and water. This zeroslump concrete mixture, when placed with an asphalt paver and compacted to high density, provides a high-strength, durable pavement structure. RCC uses no forms, requires no conventional finishing, and needs no dowels or reinforcing steel, making it an economical choice. The low water-cement ratio (usually ranging from 0.30 to 0.40) provides for very high strengths. Common design unconfined compressive strengths for pavements are in the range of 35 to $55 \mathrm{MPa}$. With the low water-cement ratio there is less paste in the concrete matrix, so there is no bleed water and less shrinkage than in conventional PCC.In the past 30 years it has gained acceptance as a strong and durable pavement material that can withstand heavy loads and severe climates with little required maintenance.
\end{abstract}

Keywords: roller-compacted concrete, pavement, properties, materials, durability.

\section{INTRODUCTION}

Roller compacted concrete (RCC) is a stiff, zero-slump mixture. The material prepared as a dry concrete is transported by dump trucks to the manufacturing laid in layers by grader or similar construction equipment and the compaction process is carried out by vibratory rollers. RCC can be manufactured with various types of aggregates (natural gravel, crushed, recycled),cementitious materials (cements, fly ash, slag, etc.) using relatively lower water and binder contents [1]. Low porosity concrete leads to high strength and long term durability and thus it is important to optimise compaction procedures so that the compacted material is adequately packed.

The American Concrete Institute $(\mathrm{ACl})$ in Cement and Concrete Terminology (ACl 1 16R-99) defines roller-compacted concrete (RCC) as, "concrete compacted by roller compaction; concrete that, in its unhardened state, will support a roller while being compacted. Properties of fully compacted, hardened RCC are similar to those of conventionally placed concrete [2].

\footnotetext{
*Authors for correspodence: Gordana Topličić-Đuričić, Email:gogatc@gmail.com

Paper received: 23. 02. 2015.

Paper accepted: 17. 04. 2015.

Paper is available on the website: www.idk.org.rs/casopis
}

Guide for roller - compacted concrete pavements, National Concrete Pavement technology Center, Institute for Transportation, lowa State University, August 2010 [3], gives an answer to a question:" What is Roller-Compacted Concrete Pavement?" Roller-compacted concrete (RCC) gets its name from the heavy vibratory steel drum and rubber-tired rollers used to compact it into its final form. RCC has similar strength properties and consists of the same basic ingredients as conventional concrete-well-graded aggregates, cementitious materials, and water-but has different mixture proportions. The largest difference between RCC mixtures and conventional concrete mixtures is that RCC has a higher percentage of fine aggregates, which allows for tight packing and consolidation [3].

In RCC the amount of cement is usually between 100 and $200 \mathrm{~kg} / \mathrm{m}^{3}$, the water content varies from $100 \mathrm{~kg} / \mathrm{m}^{3}$ to $150 \mathrm{~kg} / \mathrm{m}^{3}$ and the air content is around $1-3 \%$. However, in RCC larger coarse aggregate particles are used compared to conventional concrete. In RCC the maximum aggregate size ranges from $50 \mathrm{~mm}$ to $75 \mathrm{~mm}$. As transport, laying and compaction of RCC are very simple and practical it is much more economical than conventional concrete in terms of time and cost. RCC can also be used in composite systems as base material [4]. 
RCC pavements are strong, dense, and durable. These characteristics, combined with construction speed and economy, make RCC pavements an excellent alternative for parking and storage areas; port, intermodal, and military facilities; highway shoulders; streets; and highways.
RCC pavements are constructed without forms, dowels, or reinforcing steel. Joint sawing is not required, but when sawing is specified, transverse joints are spaced farther apart than with conventional concrete pavements [5]. Figure 1. shows conctruction of road made of RCC.
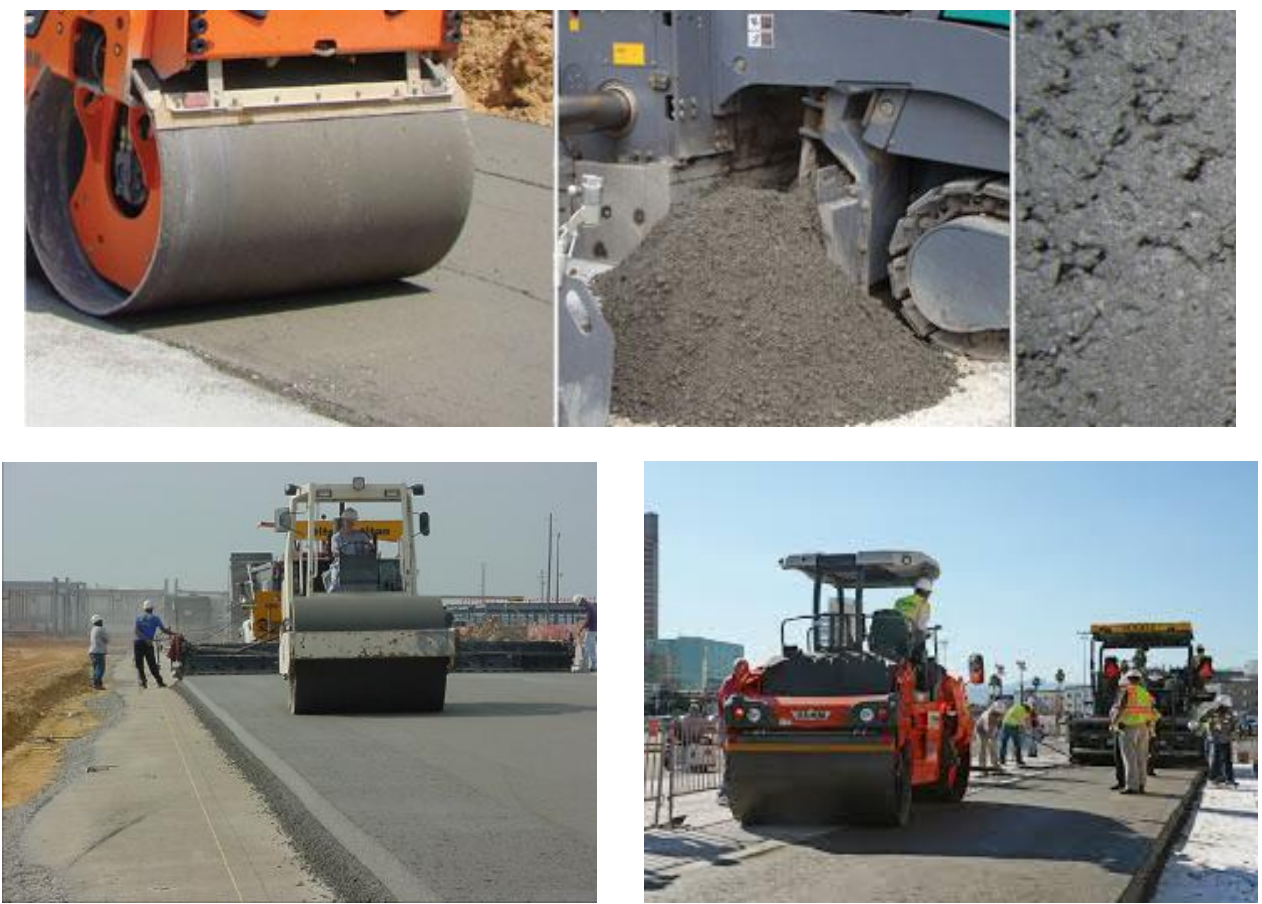

Figure 1 - Construction of a road made of RCC

Table 1 - Comparison of conventional concrete and RCC materials

\begin{tabular}{|l|l|l|}
\hline $\begin{array}{c}\text { General Materials } \\
\text { and Practices }\end{array}$ & \multicolumn{1}{|c|}{ Conventional Concrete Pavements } & \multicolumn{1}{|c|}{ RCC Pavements } \\
\hline $\begin{array}{l}\text { Mix materials } \\
\text { proportions }\end{array}$ & $\begin{array}{l}\text { Well-graded coarse and fine aggregates typically } \\
\text { account for } 60 \text { to } 75 \text { percent of the mixture by volume. } \\
\text { A typical waterto-cementitious materials (w/cm) ratio is } \\
0.40 \text { to } 0.45, \text { which makes a cement paste wet enough } \\
\text { to thoroughly coat the aggregate particles and fill } \\
\text { spaces between the particles. }\end{array}$ & $\begin{array}{l}\text { Dense- and well-graded coarse and fine } \\
\text { aggregates typically comprise } 75 \text { to } 85 \\
\text { percent of RCC mixtures by volume. RCC } \\
\text { mixtures are drier than conventional } \\
\text { concrete due to their higher fines content } \\
\text { and lower cement and water contents. }\end{array}$ \\
\hline Workability & $\begin{array}{l}\text { The mixture is plastic and flowable, so that it can be } \\
\text { manipulated by the paving machine, and relatively stiff } \\
\text { (slump is generally about } 5 \mathrm{~cm} \text { to hold shape after } \\
\text { being extruded from the paving machine. }\end{array}$ & $\begin{array}{l}\text { The mixture has the consistency of damp, } \\
\text { dense-graded aggregates. RCC's } \\
\text { relatively dry and stiff mixture is not fluid } \\
\text { enough to be manipulated by traditional } \\
\text { concrete paving machines. }\end{array}$ \\
\hline
\end{tabular}

The construction of all concrete pavements involves mechanical (consolidation) and chemical (hydration) processes. For conventional concrete pavement, consolidation occurs through internal paving machine vibrators. Through the hydration process, the paste hardens to bind the aggregate particles together. For RCC pavements, consolidation occurs through conventional or high-density paving screeds followed by steel drum and rubbertired rollers. As with conventional concrete, the pa- ste hardens through hydration to bind aggregate particles together within the RCC mixture. The result is a dense pavement that has properties similar to those of conventional concrete pavement [6]. Table 1. shows comparison of conventional concrete and RCC materials.

Figure 2. show comparison of aggregate distribution of conventional portland cement concrete (PCC, left) and RCC (right). 

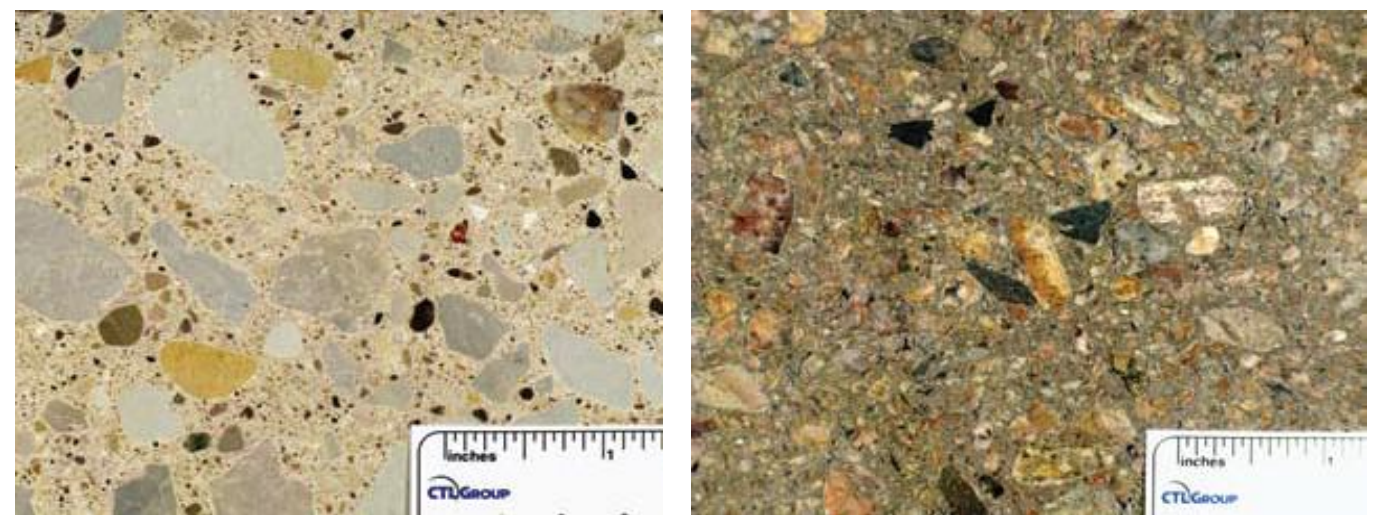

Figure 2 - Comparison of aggregate distribution of conventional Portland cement concrete (PCC, left) and RCC (right)

\section{HISTORY OF ROLLER COMPACTED CONCRETE}

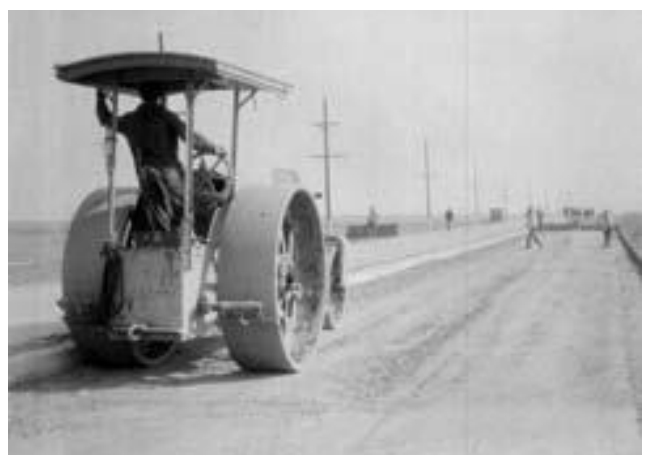

Figure 3a-1930s:A form of RCC paving is performed in Sweden

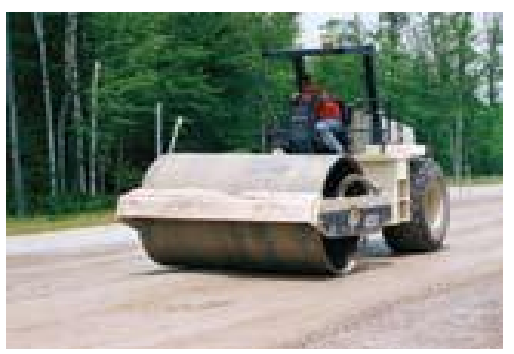

Figure 3b - 1970s:RCC pavements become common for log-sorting yards in Canada

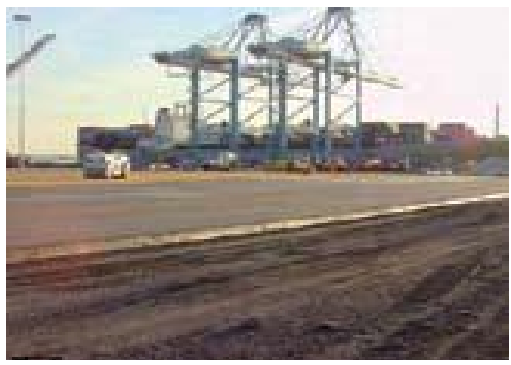

Figure 3c - Late 1980s-early 1990s: RCC pavements are constructed for automotive, port, and intermodal facilities in the U.S.
Figure 3. a,b,c show history of roller compacted concrete. While some early examples of RCC dating back to the 1930's and 1940's have been reported [7], the first widespread use of RCC was in the 1970's by the Canadian logging industry when the new land-based log sorting methods needed a strong, fast but economic paving system that could take the massive loads and handling equipment. RCC provided the solution. As appearance was not in this case a primary concern, they did not even provide joints but let the concrete crack, and this made RCC an even more economic solution.

From the 1980's onwards the use of RCC has increased for technical and economical reasons. Figure 4. show ends of a broken test beam from the Fort Hood, Texas tank stand (1984.) show internal structure of the RCC pavement.

In the USA, data from Pittman [8] showed that in 1998 about 2.5 million square meters of RCC was constructed and by 2008 this had increased to 8 million $\mathrm{m}^{2}$, i.e. more than tripled in ten years.

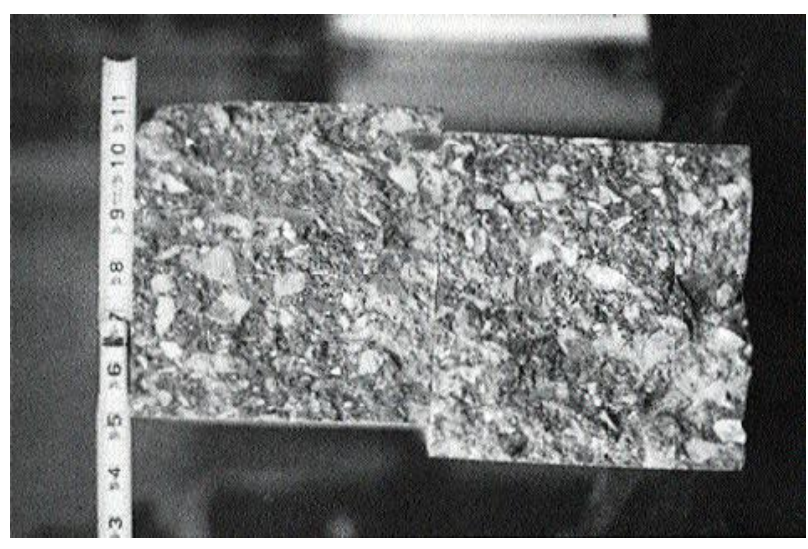

Figure 4 - Ends of a broken test beam from the Fort Hood, Texas tank stand (1984) show internal structure of the RCC pavement 


\section{RCC MATERIALS}

RCC contains the same basic materials as conventional concrete-coarse and fine aggregates, cementitious materials (cement, fly ash, silica fume, etc.), water, and, when appropriate, chemical admixtures-but they are used in different proportions. The cost of materials used in RCC is generally comparable to the cost of materials used in conventional concrete. RCC typically has a slightly lower cement content than conventional concrete of similar strength. The lower cement content can lead to some savings in material costs.

\subsection{Aggregates}

Mineral aggregates constitute up to $85 \%$ of the volume of RCC and play an influential role in achieving the required workability, specified density in the field under vibratory compaction, compressive and flexural strengths, thermal properties, long-term performance, and durability.

As with conventional concrete, aggregates for RCC should be evaluated for quality and grading. Aggregate for RCC should meet the same standards for quality and grading as required for conventional concrete construction [9].

Early RCC mass concrete dam projects in the United States used a 75-mm nominal maximum size of aggregate; however, a $50-\mathrm{mm}$, preferably crushed coarse aggregate, is less prone to segregation and is becoming more widely used.

Although larger sizes have been successfully used in Japan and at Tarbela Dam in Pakistan, the use of larger aggregate greatly increases the probability of segregation during transporting and spreading, and seldom significantly reduces the cost [10].

Maximum size aggregate for other applications include overtopping protection for embankment dams, which frequently use a nominal maximum size of aggregate is $25 \mathrm{~mm}$, since lifts are typically thinner than for mass concrete placement [11].

For RCC pavement projects a nominal maximum size of aggregate is $16-19 \mathrm{~mm}$ is typically specified. In addition to minimizing the chance for segregation during handling and placement, a smaller nominal maximum size of aggregate provides a relatively smooth pavement surface texture.

\subsubsection{Coarse aggregates}

Aggregate for RCC should meet the standards for quality and grading as required by the desired properties for the design structure. The typical nominal maximum size of aggregate particle which has been handled and compacted in construction is $75 \mathrm{~mm}$. However, the gradings may be significantly different than those normally used for conventional mass concrete.

While larger sizes have been successfully used in Japan the use of nominal maximum size of aggregate larger than $75 \mathrm{~mm}$ will seldom be technically justified or economically viable in most Corps of Engineers structures. Use of larger aggregate greatly increases the probability of segregation during transporting and spreading RCC and seldom significantly reduces the RCC cost.

A proposal to use aggregate larger than $75-\mathrm{mm}$ nominal maximum size should be included in a design memorandum and should be accompanied by results from an investigation showing that the larger aggregate can be handled without segregation, can be compacted, and that its use will actually result in lower costs [12].

\subsubsection{Fine aggregates}

The RCC aggregate skeleton to be consolidated under compaction efforts is significantly affected by the fine aggregates. A higher amount of fine aggregates allows for the reduction of cement and corresponding paste, which, when balanced by the proper gradation with coarse aggregate, provides for a compactable and durable mixture. Natural fine aggregates, which tend to be more rounded, are often used in RCC to form a strong matrix. Aggregate from crushed stone may also be used.

Silts and clays in RCC aggregates should be avoided because they can increase shrinkage and reduce strength.

The allowable percentage passing the $75 \mathrm{~m}$ sieve should be between 2 and 8 percent. This specified amount of fines is used to assist in lubrication of the mix to help with cement paste distribution [12].

\subsection{Cementitious materials}

RCC can be made with any of the basic types of hydraulic cement or a combination of hydraulic cement and pozzolan. Cements that have a predetermined percentage of pozzolan or slag) can also be used in RCC mixtures.

Selection of materials for chemical resistance to sulfate attack, potential alkali reactivity, and resistance to abrasion with certain aggregates should follow procedures used for conventional concrete construction.

Supplementary cementitious materials can also be used to provide additional fine material and ensure adequate compaction, particularly in mixtures containing standardgraded concrete fine aggregate.

When low cementitious material content RCC is used, the required amount of material passing the $75 \mathrm{~mm}$ sieve is greater for RCC than is acceptable for conventional concrete.

The larger percentage of fines is used to increase the paste content in the mixture to fill voids and contribute to workability. Although the greatest benefit from the use of fines is the control 
of segregation, in many cases the use of fines increases water demand, thus lowering strength.

Fly ash will contribute substantially to the environmental sustainability of industry operations. However, in other parts of the world class $C$ fly ash, slag, and natural pozzolan have also been used [13].

If fly ash is used, it typically comprises 15 to 20 percent of the total volume of cementitious material. To prevent scaling of the concrete surface, fly ash content should not exceed 25 percent of the total volume.

Replacement of portland cement with fly ash has the following benefits:

- Lower installed and life cycle costs versus conventional pavements.

- Provides higher strengths, and greater long term durability.

- Improves workability and place-ability due to the spherical structure of fly ash.

- Significantly reduces alkali aggregate reaction, preventing cracks.

- Improves sulfate attack resistance, preventing expansion cracks, and loss of strength.

- Reduces the heat of hydration (by 60\%) preventing thermal cracking.

- $\mathrm{CO}_{2}$ is a significant by-product in the manufacture of portland cement. Every ton of portland cement that is replaced with fly ash in a concrete mixture, prevents one ton of $\mathrm{CO}_{2}$ being released into the atmosphere.

Appropriate production and handling of fly ash complements the environmental objectives of utilities and cement manufacturers. This presents an opportunity for collaboration between the utility and cement industries to "green" their respective operations and reduce costs. And as the value, allocation and trading of $\mathrm{CO}_{2}$ emission credits evolve over the next several years, the recycling and responsible use of fly ash.

Slag or silica fume can also be used in RCC mixtures.

Silica fume can increase the strength and freeze - thaw durability of concrete but can also increase the amount of compaction effort required. In cold weather regions, silica fume can improve the mechanical properties and speed up the strength development of RCC mixtures. Silica fume is mostly used in blended cements at a replacement level of 7 to 8 percent.

When pozzolans are used to replace natural fines, workability improves while $w /(\mathrm{cm})$ ratios decrease and long-term strength may increase [9].

\subsection{Chemical admixtures}

Chemical admixtures are used differently in RCC than in conventional concrete because the much lower volume of paste makes it more difficult to incorporate many admixtures. While its low water/cement ratio helps give RCC its highstrength properties, there are times when certain admixtures may be considered, such as:

- Set retarders can be used to delay the setting time of the cementitious materials and are useful when there is a long haul time between the point of production and the project location.

- Set accelerators can be used if the intent is to speed the setting time of the RCC, such as when opening a project early to traffic.

- Water reducers and plasticizers can help distribute the small amount of cementitious paste uniformly throughout the RCC mix and improve speed and workability during production and placement.

- Air-entraining admixtures are very difficult to homogenously incorporate throughout a batch of RCC due to the extremely dry nature of the mix and are not commonly used [12].

\section{BENEFITS}

Benefits of RCC for pavements are:

- The primary advantage of RCC over conventional construction is in the speed of construction and cost savings. Trafficking at much earlier ages than with conventional pavement concrete is possible due to its rapid gain of strength.

- Durability

- Low maintenance

- Light surface reduces lighting requirements and Urban Heat Island effects (RCC pavements have a solar reflectance index (SRI) greater than the minimum 29 required for Leadership in Energy and Environmental Design [7].

- The lower paste content in RCC results in less concrete shrinkage.

- RCC can be designed to have high flexural, compressive, and shear strengths.

- With its low permeability, RCC provides excellent durability and resistance to chemical attack, even under freeze-thaw conditions.

- RCC resists abrasion, similar to conventional concrete pavement.

- Freeze-thaw durability of RCC is high.

\section{THE POSSIBLE LIMITATIONS AND CHALLENGES}

- Without diamond grinding, RCC's profile and smoothness may not be desirable for

- pavements carrying high-speed traffic.

- The amount of RCC that can be mixed in a transit mixer or ready mix truck is typically lower than for conventional concrete, due to the dryness of the RCC mix 
- Due to relatively low water content, hotweather RCC paving requires extra vigilance to minimize water loss to evaporation.
- Due to the dryness of the RCC mixture, admixture dosage requirements can be higher for RCC than for conventional concrete [8].

Table 2. show factors considered in RCC mixture proportioning.

Table 2 - Factors considered in RCC mixture proportioning

\begin{tabular}{|c|c|c|c|}
\hline \multicolumn{4}{|c|}{ Factors considered in RCC mixture proportioning } \\
\hline $\begin{array}{l}\text { Constructability } \\
\text { Mix is constructable, } \\
\text { achieves required density } \\
\text { with optimal compaction } \\
\text { effort }\end{array}$ & $\begin{array}{l}\text { Mechanical strength } \\
\text { Compressive strength, } \\
\text { flexural strength }\end{array}$ & \begin{tabular}{l}
\multicolumn{1}{c}{ Economics } \\
Use of locally available \\
materials, lower cement \\
consumption, \\
use of supplementary \\
cementitious materials
\end{tabular} & $\begin{array}{c}\text { Durability and } \\
\text { performance }\end{array}$ \\
\hline
\end{tabular}

\section{MIXTURE PROPORTIONING}

Some of the methods of design of RCC for pavement are:

Corps of Engineers Method - This proportioning method is based on $\mathrm{w} / \mathrm{c}$ and strength relationship. The method calculates mixture quantities from solid volume determinations, as used in proportioning most conventional concrete. The approximate water demand is based on nominal maximum size aggregate and desired modified Vebe time. A recommended fine aggregate as a percentage of the total aggregate volume is based on the nominal maximum size and nature of the course aggregate. Once the volume of each ingredient is calculated, a comparison of the mortar content to recommended values maybe made to check the proportions [12].

High Paste Method - This method results in mixtures that generally contain high proportions of cementitious materials, high pozzolan contents, clean and normally graded aggregates and high workability. The optimum water, fine aggregate, and coarse aggregate ratios are determined by trial batches Vebe consistencies are typically determined in accordance with ASTM Test Method for Determining the Consistency and Density of Roller-Compacted Concrete (C 1170). The major advantage of the high paste method is to provide excellent lift-joint bond strength and low joint permeability by providing sufficient cementitious paste in the mixture to enhance performance at the lift joints [12].

Roller-Compacted Dam Method - The rollercompacted dam (RCD) method is used primarily in Japan. The method is similar to proportioning conventional concrete in accordance with $\mathrm{ACl}$ 211.1 (Recommended Practice for Selecting Proportions for Concrete) except that it incorporates the use of a consistency meter. The procedure consists of determining relationships between the consistency, termed VC value, and the water content, sand-aggregate ratio, unit weight of mortar, and compressive strength. Because of the consistency test equipment requirements and differences in the nature of RCD design and construction, this method is not widely used in proportioning RCC mixtures outside of Japan [12].

Maximum Density Method - This method is a geotechnical approach similar to that used for selecting soil-cement and cement stabilized base mixtures. Proportioning by this approach is also covered in Appendix 4 of $\mathrm{ACl}$ 211.3. (Guide for Selecting Proportions for No-Slump Concrete). Instead of determining the water content by Vebe time or visual performance, the desired water content is determined by moisture-density relationship of compacted specimens, using ASTM Test Method for Laboratory Compaction Characteristics of Soil Using Modified Effort (D 1557). Another method for proportioning nonairentrained RCCP mixtures is referred to as the optimal paste volume method. The premise behind the method is that workability and strength requirements are treated in two independent steps. The method is based on the assumption that an optimal RCC should have just enough paste to completely fill the interstices remaining when the granular skeleton has reached its maximum density under compaction [12].

\section{RCC PROPERTIES}

The properties of RCC are similar to those of conventional concrete pavement but are achieved using different mixture proportions and construction techniques. Data describing the engineering properties of RCC pavements are based on tests of cylinders from actual paving projects as well as fullscale test sections. 


\subsection{Smoothness}

RCC pavements are not as smooth as conventional PCC pavements.

If pavement smoothness is particularly important for a RCC project, the following steps can be taken to improve the final results:

- use a maximum aggregate size no larger than $13 \mathrm{~mm}$

- do not construct the pavement in layers exceeding $200 \mathrm{~mm}$ in thickness (after compaction)

- use a high-density paver with string-line grade control

- be able to achieve compaction without excessive rolling

If high-speed operations are required, a thin (50 to $75 \mathrm{~mm}$ ) layer of asphalt or bonded concrete can be placed over the RCC slab to provide a smooth travelling surface. Diamond grinding of the RCC surface has also been used, and can provide additional smoothness without the construction of a surface overlay [9].

Figure 5. illustrates surface texture of RCC, PCC (conventional concrete) and HMA (asphalt).

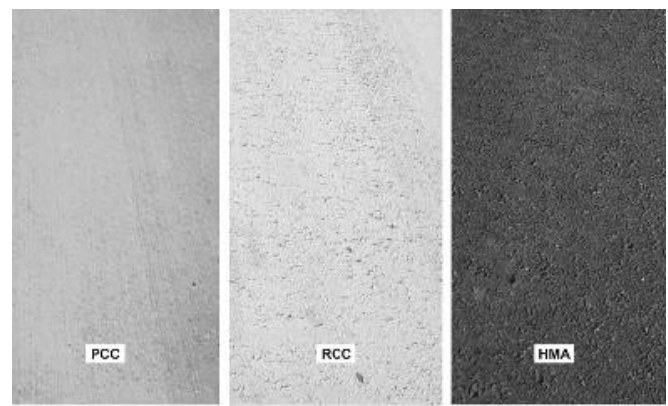

Figure 5 - Surface texture of RCC compared to conventional concrete (PCC) and asphalt (HMA)

\subsection{Compressive strengths}

A major advantage of RCC over pavement quality concrete is the ability to open it to traffic at a relatively early age. A "rule of thumb" used in the USA [14] is to open it to traffic when the compressive in-situ strength reaches about 20 $\mathrm{N} / \mathrm{mm}^{2}$ cylinder strength. The rate of gain of strength is highly dependent upon a number of factors including cement type, RCC strength and the ambient conditions, all of which are site specific. In practice the requirement of $20 \mathrm{~N} / \mathrm{mm}^{2}$ is achieved in about 2 days in warm weather and about 4 days in cooler weather. The model specification has the more onerous requirement of 7 days after construction before trafficking. In most cases, a shorter period is not needed, but where it is an issue, the achievement of an in-situ strength of $20 \mathrm{~N} / \mathrm{mm}^{2}$ is the fundamental criterion. These requirements relate to trafficking by the public and not to trafficking by the contractor. The RCC will have been compacted by heavy machinery and therefore occasional site traffic is unlikely to harm the RCC. The compressive strength of RCC is comparable to that of conventional concrete, typically ranging from 28 to $41 \mathrm{~N} / \mathrm{mm}^{2}$. Some projects have reached compressive strengths higher than $48 \mathrm{MPa} \mathrm{N} / \mathrm{mm}^{2}$.

\subsection{Flexural strength}

Flexural strength is directly related to the density and compressive strength of the concrete mixture. In properly constructed RCC pavements, the aggregates are densely packed and minimize the development of fatigue cracking. The density of the paste and the strength of its bond to the aggregate particles are high due to its low $\mathrm{w} / \mathrm{cm}$ ratio. As a result, the flexural strength of $\mathrm{RCC}$, depending on the mix design, is generally high ranging from 3.5 to $7 \mathrm{~N} / \mathrm{mm}^{2}$.

\subsection{Volume change}

Volume change associated with drying shrinkage is normally less than that in comparable conventional concrete mixtures due to the lower water content.

\section{DURABILITY AND PERMEABILITY}

RCC, as an engineering material, can be considered to be impermeable. Because the shrinkage cracks are narrow, very little water moves through to the bottom of the slab, and good aggregate interlock has made the problems associated with pumping of RCC pavements very rare. The durability of RCC pavement is excellent, both in terms of environmental effects, and the physical wearing caused by equipment operations. In some cases a small amount of wear will occur (less than $6 \mathrm{~mm}$ ) on the pavement surface if it was not adequately bonded during construction. However, experience indicates that this wear will be arrested and will not increase even after years of traffic and abrasion [15].

\subsection{Abrasion/erosion resistance}

Compressive strength and aggregate size, grading, and quality primarily govern abrasion/erosion resistance. Erosion tests in test flumes have indicated the excellent erosion resistance for RCC. Research has indicated that the abrasion resistance of RCC increased with increasing strength and maximum aggregate size. In fact, some studies indicated that aggregates contributed more to abrasion resistance than cement content. Observations of various projects from heavy-duty pavements such as log sort yards to RCC spillways have also indicated excellent resistance to abrasion/erosion [16].

\subsection{Freezing and thawing}

In Piggott's study [11] a total of 34 RCC pavement projects in the United States and Canada were visually inspected. The projects ranged in age 
from 3-20 years. The study concluded that except for some surface wear (fines were removed up to a depth $2 \mathrm{~mm}$ ), the performance of the RCC was very good. The coarse aggregate at the surface remained firmly embedded in the RCC matrix. The study also noted that surface wear typically occurred within the first 2-3 years of service and then stabilized [16].

When RCC is used in freeze-thaw (F-T) conditions, the following practices should be considered:

- Use of sound, non-deleterious, durable aggregate

- Use of a dense, well-grade aggregate

- Use of an adequate quantity of portland cement and increase paste content

- Compaction to at least $98 \%$ of the modified Proctor density

- Reduction of $\mathrm{w} / \mathrm{cm}$ ratio to less than 0.40

- Use of silica fume as a partial replacement for cement

- Use of air entrainment additives when compatible with mixer

- Proper and timely curing

\subsection{Shrinkage}

Any significant change in volume experienced with RCC pavements is due to drying shrinkage. However, the volume change associated with drying shrinkage is normally less than that in comparable conventional concrete mixtures due to the lower water content of RCC. Thus, a lower volume of cement paste results in lower shrinkage and less cracking for RCC pavements. Research has also found that in a mixture with a constant cement amount, drying shrinkage decreases as the amount of coarse aggregate increases, due to high restraint (Pittman and Ragan 1998). With respect to thermal considerations, heat rise that causes expansion of a massive concrete structure is due almost entirely to the chemical reactions of the cementitious material.

Therefore, the use of lesser amounts of cementitious material in mass RCC construction lowers the potential for thermal cracking. $[3,17]$.

\subsection{Permeability}

The permeability of RCC is largely dependent on voids in the compacted RCC, together with the porosity of the mortar matrix, and therefore is almost totally controlled by mixture proportioning, placement method, and degree of compaction. Hardened RCC permeability is comparable to that of conventional concrete.

\section{MAINTENANCE}

RCC pavements have shown to require very little maintenance. Cracks are sometimes routed and sealed, but usually crack spalling is not a significant problem.

The most common type of repair occurs with small areas where the RCC may have been placed by hand, or around structures. In these locations, if the RCC is not satisfactory, it can be removed and replaced with a repair using conventional concrete [10].

\section{CONCLUSION}

The use of RCC as a material to construct pavements began in the 1970's in Canada. It was originally used by the logging industry to provide an all-weather platform for unloading logging trucks and storing and sorting logs. In the past 30 years it has gained acceptance as a strong and durable pavement material that can withstand heavy loads and severe climates with little required maintenance [18].

The principal advantages of RCC pavements are derived from the construction process used to create them. Construction costs are lower because there is less labor involved in placing the concrete (no formwork or finishing is required), and no reinforcing steel or dowels are used. With the low water-cement ratio there is less paste in the concrete matrix, so there is no bleed water and less shrinkage than in conventional PCC. The dominant role of aggregate in the concrete provides load transfer across control joints and cracks by using aggregate interlock, which eliminates the need for load transfer devices [18].

Additional research and development is needed to:

1.) improve surface texture, skid resistance, and joint construction methods in pavements;

2.) establish standardized joint design spacing;

3.) establish standardized mixture design methods;

4.) develop representative freeze -thaw durability test procedures;

5.) determine methods - for air-entrainment,

6.) improve mixing efficiency using conventional concrete mixing equipment; and

7.) expand the use of admixtures including retarders and water reducers to extend working time and enhance performance [5].

\section{Acknowledgements}

The work reported in this paper is a part of investigation within the research project TR 36017 „Utilization of by - products and recycled waste materials in concrete composites in the scope of sustainable construction development in Serbia: investigation and environmental assessment of possible applications" supported by Ministry for Science and Technology, Republic of Serbia. This support is gratefully acknowledged. 


\section{REFERENCES}

[1] Ch. Hazaree, H. Ceylan, K. Wang (2011) Influences of mixture composition on properties and freezethaw resistance of RCC", Construction and Building Materials 25, 313-319

[2] "Cement and Concrete Terminology,"(2010) ACI 116R-99, Manual of Concrete Practice, Part 1, American Concrete Institute, Farmington

[3] "Guide for roller - compacted concrete pavements", National Concrete Pavement Technology Center, Institute for Transportation, lowa State University, august 2010

[4] Ali Mardani-Aghabaglou, K. Ramyar (2013) "Mechanical properties of high-volume fly ash roller compacted concrete designed by maximum density method", Construction and Building Materials 38 , 356-364

[5] W. S. Adaska (2006) "Roller-Compacted Concrete (RCC)", PCA R\&D Serial No. 2975, Reprinted by permission of ASTM International, West Conshohocken, Pennsylvania.

[6] "Guide Specification for Highway Concrete Pavements", Commentary, October 2012

[7] ERMCO "Guide to roller compacted concrete for pavements", April 2013, Yowa State Universitaty, Institute for transportation

[8] O.Jr.Keifer (1986) "Paving with Roller Compacted Concrete," Concrete Construction, March 1986, pp. 287-297.

[9] L.Gaekel, K.E.Schrader, E. K.(1992) "RCC Mixes and Properties Using Poor Quality MaterialsConcepcion Dam," Roller Compacted Concrete 111, American Society of Civil Engineers, New York, NY.
[10] "Roller Compacted Concrete" (2000) Engineer Manual No. 1110-2-2006, U.S. Department of the Army, Corps of Engineers, Washington, DC.

[11] "Roller Compacted Mass Concrete" (1999) ACl 207.5R-99, Manual of Concrete Practice, Part 1, American Concrete Institute, Farmington Hills, MI.

[12] E.Gregory, P.E.Halsted (2009) Roller-Compacted Concrete Pavements for Highways and Streets, Annual Conference of the Transportation Association of Canada Vancouver, British Columbia

[13] "Engineering and Design Roller Compacted Concrete" (2000) Department of the army U.S. Army Corps of Engineers, Wasington, DC 203141000, Manual No. 1110-2-200615.

[14] R.W.Piggott (1999) "Roller Compacted Concrete Pavements-A Study of Long Term Performance," RP366, Portland Cement Association, Skokie, IL.

[15] Muayad Umar Rashed (2000) "Roller Compacted Concrete (RCC) innovations in Civil Constructions world by Civil engineer", Site Enginner Mass - Iraq for Iron \&nSteel Industry Sulaymaniyah

[16] "Roller Compacted Concrete" (2000) Engineer Manual No. 1110-2-2006, U.S. Department of the Army, Corps of Engineers, Washington, DC.

[17] W.O.Tynes (1973) "Feasibility Study of No-Slump Concrete for Mass Concrete Construction," Miscellaneous Paper No. C-73-10, U.S. Army Engineer Waterways Experiment Station, Vicksburg, MS.

[18] D.J.Hall, Dn.Low (1974) "Roller Compacted Concrete Studies at Lost Creek Dam," U.S. Army Engineer District, Portland, OR.

\section{IZVOD}

\section{SVOJSTVA, MATERIJALI I TRAJNOST VALJANOG BETONA ZA KOLOVOZ}

Valjani beton (RCC) je projektovana betonska mešavina koja se sastoji od zbijenog separisanog agregata, cementa $i$ vode. Ova betonska mešavina čija je vrednost sleganja nula, prilikom ugrađivanja sa asfaltnim finišerom i kada je sabijena do velike gustine, daje veoma čvrstu $i$ trajnu kolovoznu konstrukciju. Za RCC se ne koriste oplate, nije potrebna konvencionalna završna obrada i ne koriste se dilatacione razdelnice ili armaturni čelik, što ga čini ekonomičnim. Mala vrednost vodocementnog faktora (obično se kreće od 0,30 do ,0,40) obezbeđuje veliku čvrstoću. Uobičajene projektovane vrednosti čvrstoće pri pritisku nalaze se u opsegu od 35 do $55 \mathrm{~N} / \mathrm{mm}^{2}$. Zbog male vrednosti vodocementnog faktora i manje količine paste u betonskoj matrici, ne dolazi do „krvarenja“ betona, osim toga, skupljanje je manje nego kod konvencionalnih betona od portland cementa. U proteklih 30 godina, prihvaćen je kao jak i trajan kolovozni materijal koji može da izdrži velika opterećenja i oštru klimu uz malo potrebnog održavanja.

Ključne reči: valjani beton, kolovoz, svojstva, materijali, trajnost.

Naučni rad

Rad primljen: 23. 02. 2015.

Rad prihvaćen: 17. 04. 2015.

Rad je dostupan na sajtu: www.idk.org.rs/casopis 